\title{
The trowel and the sickle. Italian archaeology and its Marxist legacy
}

\author{
Elisa Cella ${ }^{1}$, Maja Gori ${ }^{2}$, Alessandro Pintucci ${ }^{34}$
}

${ }^{1}$ Museo Civico Etrusco Romano di Trevignano Romano, ${ }^{2}$ University of Heidelberg, ${ }^{3}$ Sapienza University of Rome

\begin{abstract}
:
During the second post-war period (1945-1960s), the Italian Communist party was a hub of intellectuals, and as such influenced the development of Italian archaeology as well. Marxist ideology indeed was perceived as means to enfranchise the discipline from the old academia. Focusing on of the socalled "Roman school" of archaeology, this paper analyzes the influence of communist and Marxist ideologies on the discipline's development. In particular we will present two prominent and charismatic archaeologists Renato Peroni and Andrea Carandini. It is argued that while the Marxist research trajectories were characterized by an initial innovative and driving force that revolutionized Italian archaeology, the collapse of the Italian Communist Party and the resulting downfall of its intellectual tradition determined the exhaustion of the discipline's innovative potential.
\end{abstract}

Keywords: Italy, Marxism, Communism, Archaeology.

\section{Introduction}

During the second post-war period (1945-1960s), the Italian Communist party (PCI - Partito Comunista Italiano) - amongst the larger of the Western Bloc - deeply influenced the development of Italian archaeology: not only did the PCI play a major role during the national liberation from Nazism and Fascism in 1945, it was also a crucial hub for Italian intellectual life. In particular, its 'think tank' had a profound impact on theoretical approaches to the humanities, and archaeology was no exception. Several archaeologists, indeed, were deeply swayed by communist ideology, which was perceived as means to enfranchise the discipline from the old academia still imbued with fascist ideology.

By focusing on the development of Italian archaeology from the 1960s onwards, this paper will analyze the influence of communist and Marxist ideologies on the development of the discipline. In particular, the academic trajectories of Andrea Carandini and Renato Peroni, two outstanding archaeologists belonging the socalled Roman School, will be discussed. These scholars were the main figures around which two groups of archaeologists gathered. The first, mainly composed of classicists, clustered around the journal Dialoghi di Archeologia, while the second was formed by pre- and proto-historic archaeologists belonging to the Centro Studi per la Protostoria.

Carandini's and Peroni's scientific trajectories, their connection with the Italian Marxist tradition and the PCI, and their relation to the Dialoghi and the Centro Studi groups respectively, will be discussed by adopting a diachronic perspective focusing on the period starting from the 1960s until the beginning of the 1990s, when the PCI dis-

${ }^{4}$ All authors have contributed equally to the ideas at the basis of this work. Individual author's contribution is specified at the end of each paragraph (EC/MG/AP).

CONTACT Elisa Cella, eli.cella@libero.it - Maja Gori, maja.gori@zaw.uni-heidelberg.de - Alessandro Pintucci, alessandro.pintucci@uniroma1.it 
solved. The collapse of the communist governments in the Soviet Union and Eastern Europe, indeed, had deep reverberations throughout Italy. Similarly to other European Communist parties, the PCI undertook the long path of reform that turned it into a left-wing progressive party. It is argued that while the Marxist research trajectory epitomized by the two scholars was characterized by an initial innovative and driving force that revolutionized Italian archaeology, the collapse of the Italian Communist Party and the resulting downfall of its intellectual tradition, led to the exhaustion of the discipline's innovative potential. (EC/MG/AP)

\section{The First Time of Marxism and Archaeology}

Following the Second World War, Italian academia was still profoundly influenced by reactionary ideologies that characterized the first decades of the twentieth century. Following the Fascist Regime's end, indeed, several scholars that were active during the Ventennio Era (1922-1945) kept their preeminent positions in the Universities. The most outstanding archaeologists of the fascist era, indeed, rejected only formally their affiliation to the later Mussolini regime, in order to save their tenures, as the emblematic case of Giulio Jacopi shows (Barbanera 1998: 151-152).

At that time, two outstanding archaeologists were working at La Sapienza University of Rome: Massimo Pallottino and Ranuccio Bianchi Bandinelli. Pallottino had a conservative-oriented ideology despite his engagement with a small group of catholic intellectuals into the Resistenza, the Italian anti fascist organization. He is considered one of the most important scholars focusing on pre-Roman Etruscan civilization. In essence, he created the modern discipline of Etruscology (Etruscan civilization and art). It is important to point out the role that Etruscan civilization had in the debate on autochthonism, which characterized Italian national identity building discourse already from the Age of Enlightenment (Harari 2012: 405-418; De Francesco 2013).

Ranuccio Bianchi Bandinelli, on the contrary, had a progressive ideology, and even if he was forced to pledge his loyalty to the fascist regime, he was fervently connected to the Italian Communist Party. Bianchi Bandinelli was a remarkable archaeologist and fine intellectual, and thanks to his political engagement became the paradigm for

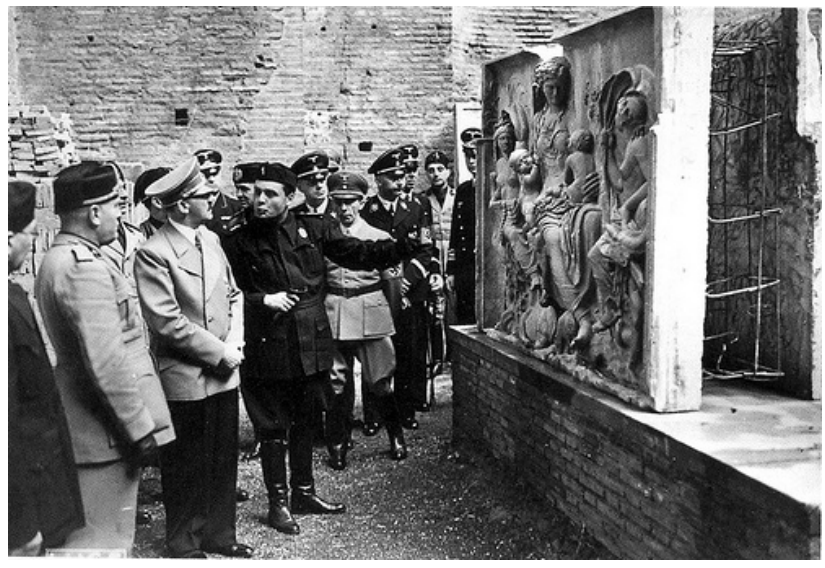

Figure 1. A black-shirt dressed Ranuccio Bianchi Bandinelli guiding Hitler and Mussolini through Museo delle Terme di Diocleziano in Rome, May 1938. the Italian intellectual communist. Born in 1900 into a noble Italian family, he started his career in 1929 as a professor of Classics at the universities of Cagliari, Groningen, Pisa, Firenze and Rome. Like the majority of intellectuals, in 1938 he swore allegiance to the fascist regime (Barbanera 1998: 150).

At the $73^{\text {rd }}$ Venice International Film Festival Enrico Caria presented a documentary focusing on the well-known visit that Hitler paid to Rome in May 1938 titled L'uomo che non cambiò la storia (The man who hasn't changed history). In that occasion, Bianchi Bandinelli was sum- 
moned by Mussolini to act as archaeological guide for the Führer. Caria's documentary is largely based on vintage material from the Istituto Luce, and focuses on Bandinelli's dilemma: if he accepts, he will be compromised with a regime that he despises, but if he refuses he will compromise his studies and his family. Bianchi Bandinelli accepted the task, and in the days preceding Hitler's visit he elaborated a plan to kill the two dictators and change the course of history that he, as we all know, didn't make effective. Bianchi Bandinelli took side against Mussolini immediately after, and joined the PCI in 1944.

As regards his intellectual activity, Bianchi Bandinelli applied Gramsci's theories to the study of Classical Art, questioning the traditional Croce aesthetic approach to antiquity. In his work, for the first time in Italy, archaeology was undertaken adopting a Marxist interpretative framework. Marxist-oriented historicism soon became a methodological issue and marked the entrance of concepts like "people" and "production" in the field of ancient art (Bianchi Bandinelli 1961). In his view, fully developed in Archeologia e cultura (1961), each masterpiece reflected social and political elements of the historical context in which it was conceived and produced. This theoretical and methodological essay exerted a profound influence on Classical studies, especially those concerned with the Roman Empire and Late Antique periods. Thanks to his revolutionary theories and charismatic personality, a group of young archaeologists fascinated by his teaching decided to graduate in Classical Archaeology.

In 1957 Bianchi Bandinelli was appointed director of the Istituto Gramsci, a position that he held until 1970. The institute was established as Fondazione Antonio Gramsci in 1950. One of the Institute's purposes was to build a structure to involve Italian intellectuals in the Communist Party cultural policy (Vittoria 2014). For decades the Gramsci Institute remained the uncontested leader of Marxist-oriented cultural policy in Italy. As Gundel (2000) pointed out, the Italian Communist party, indeed, sought to penetrate Italian society and become a force in every sphere of national life. Cultural struggle had a special significance since it was a sphere in which the party could assert a greater influence than it could in the political arena, given the barrier against its participation in government. By winning support for their ideas among writers and artists and intellectuals of all types - including archaeologists - leading Communists thought they could determine the ideas and values that were dominant in the nation (Gundel 2000, 6).

Together with Bianchi Bandinelli, Salvatore Maria Puglisi was another outstanding figure that dominated the Roman School of archaeology. During the Italian Resistance he fought together with the anglo-american troops for the liberation of Italy, and following the Second World War he became a fervent political activist. He studied at La Sapienza with Ugo Rellini, however part of his formation occurred in the United Kingdom, at University College, London, where for a period he was a student of Gordon Childe. This experience was instrumental in developing his theoretical approach to the discipline, which has been described as anthropological-functionalism (Danckers 2014: 497). When Blanc died in 1960, Puglisi was appointed professor at the University of Rome and became the first prehistorian to to apply a Marxist approach to the study of the study of ancient societies. One of the most important legacies of Puglisi is the introduction of New Archaeology in Italy. By adopting an interdisciplinary approach, he introduced 
several new disciplines in the University La Sapienza, such as African Prehistoric Ethnography, Prehistoric Ecology, and Archaeology of the Near and Middle East, and in 1962 he established the Museo delle Origini at the Faculty of Humanities, a center which served both as a didactic and scientific hub. His most important work is beyond any doubt La civiltà appenninica. Origine e sviluppo delle comunità pastorali in Italia (1959), in which he adopted an anthropological approach to the study of Bronze Age pastoral communities. In this work the concepts of infrastructure and superstructure are presented with an emphasis on economic and social tensions derived from a Marxist perspective, which in turn was probably influenced by Childe (Danckers 2014: 496-7). Puglisi also engaged in several fieldwork projects. Among the most relevant excavations that he conducted the one on the Palatine hill (Puglisi 1951 and 1953), the excavation at the Eneolithic site of Conelle di Arcevia, and the exceptional Bronze Age fortified settlement of Coppa Nevigata (Puglisi 1955) need to be remembered. Equally relevant was his research activity in Turkey at Malatya in collaboration with Alba Palmieri, in Egypt, in Sudan, and in the Libyan Sahara. Puglisi was also the founder of the scientific journal Origini, which is one of the most important journals published by the University of Rome. (EC)

\section{All Power to the Soviets! All Power to the Archaeologists!}

In 1962, on the pages of Archeologia Classica, Massimo Pallottino (1962:115-118) launched his plea calling for the unity of Italian archaeologists. Archeologia Classica was considered the most important and influential archaeological journal in Italy in the 1960s. Pallottino's plea provoked an intense debate among Italian archaeologists, which was recorded in $\mathrm{Ar}$ cheologia Classica (ArchCl. 1962: 115-118, 261-284; ArchCl. 1963: 113, 271-273; ArchCl. 1964: 319-327; Dialoghi 1967: 131-132; Barbanera 1998: 162-164). Following this exchange of ideas, the most successful proposal was the establishment of an association shaped on the model of British societies. In 1964 the Società degli Archeologi Italiani (thereafter SAI) was born (Danckers 2014: 497). Among those who were actively participating into the discussions, there were the so-called Young Archaeologists, a group of young scholars with a strong Marxist background led by Renato Peroni and based mainly in Rome. While they adhered to Pallottino's plea, nevertheless they proposed an alternative document containing political and social claims directed towards the protection of the archaeological profession (ArchCl. 1962: 261-264). Bianchi Bandinelli participated into the debate as well (ArchCl. 1962: 280-284), supporting the Young Archaeologists, despite having already abandoned the University at the time of Pallottino's plea.

In accordance with the different positions expressed during the discussions, two main blocs soon emerged within the SAI: one conservative, much closer to Pallottino's positions, and one openly revolutionary. The situation between these factions soon became tense, leading to a deep political and ideological break destined to characterize Italian archaeology for at least three decades. The internal conflicts that erupted within the SAI caused profound disappointment in the Young Archaeologists. Following their rapid escalation to leading positions, most of the old members resigned leaving to the Marxist group what R. Peroni defined as an empty nutshell (Peroni 1988: 76-82).

The social and political turmoil characterizing the end of the 1960s, pushed the Young Archaeologists to look for new spaces in which archaeology could be debated together with social and political issues. Most of archaeological journals, including Archeologia 
Classica, indeed, were publishing only 'traditional' archaeological subjects. The SAI's failure was central to the establishment in 1967 of the journal Dialoghi di Archeologia, an innovative editorial project that merged archaeological research with political engagement. Dialoghi di Archaeologia can be defined as a social experiment openly inspired by Marxism. Bianchi Bandinelli was appointed as journal's director, however he never actively participated in the project. The peculiarity of Dialoghi di Archeologia was to combine two principal sets of objectives: one theoretical and methodological, and the other, political. The journal was thus structured into two independent parts: the first, more traditional, comprising research papers, and the second, dedicated to political discussion, named Documenti e Discussioni (Documents and Discussion) and authored collectively by the Amici, where every proposal and decision were collegially taken

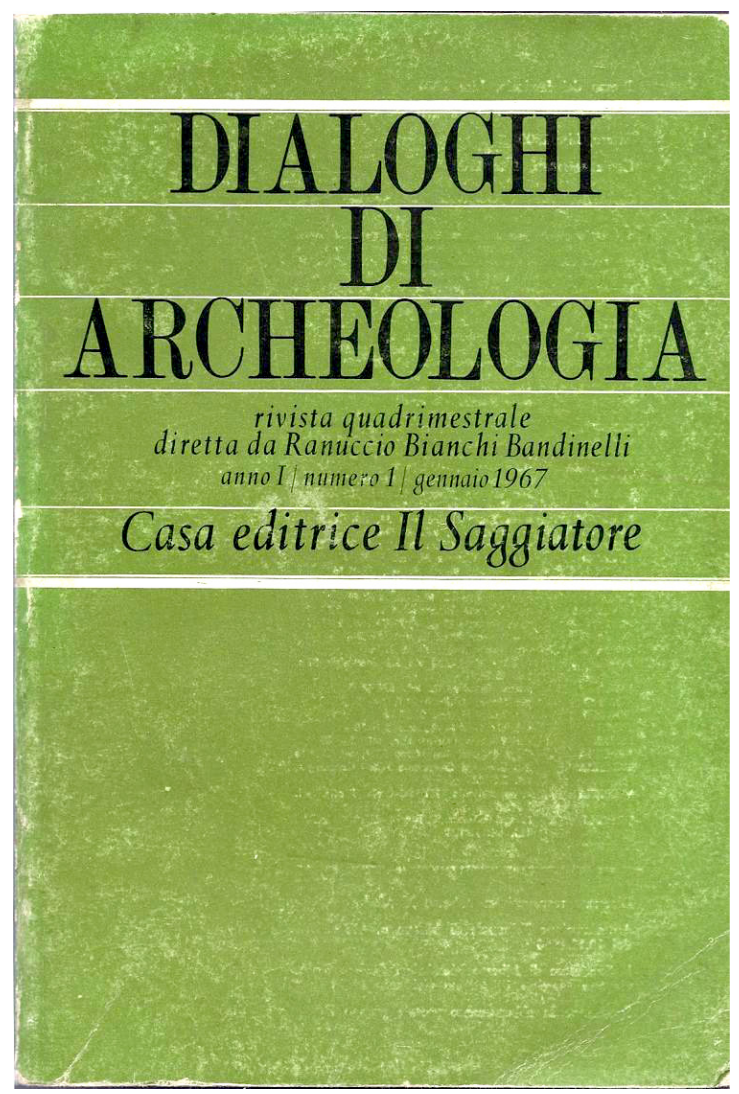

Figure 2. The cover of the first issue of Dialoghi di Archeologia.
(Iacono 2014, 3). It is worth mentioning that the journal included the first Italian open debate on the use of quantitative methods applied to Preand Protohistory (Guidi 2002: 355) thanks to two of Puglisi's former students, Alberto Cazzella and Amilcare Bietti, who organised in 1974 within the Dialoghi experience the first workshop focusing on the use of quantitative methods in archaeology.

The voluntary self-exclusion of Bianchi Bandinelli from the University in 1964 was mentioned earlier. The lack of a strong reference point within the University, disoriented the Young Archaeologists, but also favored the renovation of the discipline by giving them autonomy. Despite excavation practice was still evoking fascist digs in the center of Rome, this group of Marxist scholars stressed the necessity for new methods in archaeological excavations, advocating thus the importance of material culture in under-

standing the past. The work carried out in the pre-fascist era by scholars like Giacomo Boni, Nino Lamboglia and Luigi Bernabò Brea - the last two openly supporting the Young Archaeologists - was taken as an example to develop modern stratigraphic archaeology in Italy (Carandini 2000: 37).

Two of the most preeminent Marxist Young Archaeologists were Renato Peroni, the already mentioned Young Archaeologists' leader, and Andrea Carandini, a former Bianchi Bandinelli student. They would become two of the most outstanding scholars in their respective field of study, Protohistory and Classical Archaeology. (AP) 


\section{Typology and Chronology: the Realm of Italian Protohistory}

Renato Peroni (1930-2010) was born in Vienna into an Austrian-Italian family. He graduated in paleoethnology in Rome in 1950. From 1965 to 1971 Peroni worked at the Ethnographic Museum Luigi Pigorini (Rome) and, in 1974, he became full Professor at the University of Rome Sapienza, where he taught until 2003, when he retired. Thanks to his studies at the University of Freiburg, Peroni merged the Italian tradition of prehistoric studies with the German one, importing into Italy the division between pre- and protohistory ( $U r$ - und Frübgeschichte) that characterizes the discipline in German speaking countries. The influence of Central European historicism and cultural history approach characterized Peroni's early work (Cardarelli \& Vanzetti 2014: 516). In 1966, Peroni participated in the International Union of Prehistoric and Protohistoric Sciences (UISPP) conference held in Prague, where he was impressed by the approach to social and territorial issues of the socialist archaeologists from non-Soviet countries. Peroni's formal adhesion to historical materialism and Marxist approach developed significantly after 1968. Indeed, during the 1970s he definitively abandoned the post-war mitteleuropean historicism that had characterized his early production, which was influenced by scholars such as Gero von Merhart and Hermann MüllerKarpe (Cardarelli \& Vanzetti 2014: 516-517). The apogee of his Marxist phase is expressed in the work Le popolazioni dell'eta dei metalli, published in 1978 in the volume Archeologia (Cardarelli \& Vanzetti 2014: 518).

In a discipline dominated by Classical Archaeology, the contribution of Peroni was fundamental, both for having introduced in Italy the chrono-typological classification of artefacts and the statistic-combinatory method (1959), and having laid the foundations for a modern reconstruction of social and economic structures of prehistoric societies (Peroni 1959; Guidi 1988: 286-287; Guidi 1988: 286-287; Guidi 2015). Peroni’s approach to chrono-typological classification was very different from the one that classical archaeologists were experimenting with in the same years. This methodological difference raised a lively debate (Dialoghi 1976-77: 652-655).

In contrast to Carandini and Bianchi Bandinelli, the relationship between Puglisi and Peroni was conflicting. In particular, the point of contention was Puglisi's adoption of Childe's approach - and later of New Archaeology's principles - and Peroni's categoric opposition to any form of explanation based on or even recalling diffusionism. The fracture became irreconcilable. Vehemently opposing the diffusionist paradigm, change in material culture was explained mainly in terms of transformation within societies rather than being caused by external factors. This approach remained at the basis of Peroni's entire scientific production. The importance of the chronologic framing of archaeological facies on typological basis is evident in the titles of works like Per una definizione dell'aspetto culturale subappenninico come fase cronologica a sé stante, published in 1959, or L'età del bronzo in Italia: per una cronologia della produzione metallurgica (with Gian Luigi Carancini), published in 1999.

As a reaction, and in opposition to what he considered an old and inadequate methodological framework, he founded in 1980 in Rome and in Milan the Centro Studi per la Protostoria. Many scholars subscribed to the Centro Studis manifesto (Nizzo 2015: $184 ; 188-189)$. The research center contributed to the organization of two groundbreaking conferences and publications: Il Bronzo Finale in Italia (1980), Necropoli e usi 
funerari dell'età del ferro (1981) and Popoli e facies culturali celtiche a nord e a sud delle Alpi dal $V$ al I secolo a. C. (1983).

In one of his last works published posthumous in 2010, in criticizing Jared Diamond's Collapse (2005), he stressed once more the importance of the relation between production forces and production relations as factors of change, an element that was overlooked by the American scholar (Cardarelli \& Vanzetti 2014: 520), confirming his constant adhesion to a Marxist paradigm throughout his whole academic production. The tight connection of his research methodology to a Marxist analytical framework is also present in some of his works focusing on teaching, like the well-known Considerazioni preliminari per l'insegnamento della preistoria (1975). Besides his methodological approach to the study of material culture, one of Peroni's most important legacies is the creation of a "school". Indeed, thanks to his uncommon charisma, strong commitment to teaching, and a deep bond with his former students, he gathered a group of archaeologists who outlived him. (MG)

\section{Studying Pottery in the University's Cellar}

Andrea Carandini was born to Niccolò Carandini, the first Italian ambassador in London (Bartoli 2007), after the end of the Second World War. Carandini's interest as student at the University of Rome focused initially on Classical Philology. However, after meeting Bianchi Bandinelli, he became immediately enthusiastic of his approach to archaeology and decided to abandon the idea of a career as philologist, devoting himself to archaeology instead. With only one exam in Classical Archaeology in his curriculum studiorum, in 1962 he graduated defending a thesis with Bianchi Bandinelli as supervisor (Carandini 2000: 18).

Following Bandinelli's resignation as professor, the vacant chair of Classical Archaeology was assigned to Giovanni Becatti, who raised Carandini's interest for fieldwork and for the impressive amount of pottery collected during the Ostia excavations (Carandini 2000: 22-23). On that occasion, Becatti proved to be even more open than Bianchi Bandinelli, encouraging the young scholars to experiment with new approaches to archeology focusing on the study of pottery, which until that time had been extraordinarily neglected. ${ }^{1}$ This attention for pottery materialized into the establishment, together with Clementina Panella and Daniele Manacorda among others, of the first ceramic laboratory at the University of Rome, named Cantinone (Italian slang for large cellar) that was located in the wide faculty's basements. Following the ideological path traced by Bianchi Bandinelli's theoretical approach to the study of antiquity, Carandini modernized Classical Archaeology, merging English empiricism with Marxist historicism.

Carandini is one of the few archaeologists of his generation who wrote down his thoughts on Italian archaeology and archaeologists (Carandini 1981; Carandini 2000). Thanks to his memoirs, we know that his experiences within the PCI in the 1960s were relevant for his intellectual development. His Marxist approach entered in his scientific production through works such Archeologia e cultura materiale (1975), and L'anatomia della

\footnotetext{
${ }^{1}$ This aspect pertaining to Becatti's teaching was recently remembered by Carandini himself in the occasion of M. Medri's presentation of the last volume of the Terme del Nuotatore excavations at Palazzo Massimo in Rome in 2014.
} 
scimmia (1979), the latter focusing on a Marxist analysis applied to history. Carandini will later remember that Renato Peroni was one of the few scholars who agreed to review his Archeologia e cultura materiale (Carandini 2000: 75), published, not by chance, in Dialoghi di Archeologia (Peroni 1976-77: 648). In addition to the critics focusing on the notions of type and typology, Peroni questioned Carandini's anthropological approach, which was close to the one popular in the USA and linked to the New Archaeology. His main criticism was centered on the fact that anthropology was de facto opposite to the historical approach that characterized the Marxist methodology adopted by Peroni (1976-77: 655-657).

Between the 1970s and the 1980s Carandini excavated the Roman villa of Settefinestre, which yielded a large amount of data from which several works on the Roman slave system have stemmed: Settefinestre (1986), Schiavi in Italia (1988), Società romana e produqione schiavistica (1981), Storia di Roma (1989). His interest was mainly centered on the complexity of Roman society and on the means of production.

Part of his work, especially Società romana e produzione schiavistica and Storia di Roma, adopts a multidisciplinary approach. Carandini gathered a group of historians, anthropologists, philologists and archaeologists to work together and discuss the Roman economic system. Most of these scholars were part of the Istituto Gramsci, and once the above mentioned books were published, the group dissolved leaving a void in these fields of expertise. From the end of the 1980s, Carandini started to investigate the northern Palatine hill slopes, where he excavated relevant protohistoric contexts that he connected to the origin of Rome. Indeed, the Palatine hill was chosen for its significant connection to the foundation and the early history of the Eternal City.

In 1981 Carandini published the first stratigraphic manual in Italian, bringing to Italian scholars and above all to Italian students, the advancements in methodology of British archaeology of 1960s and 1970s.

In the same years, the Fall of the Berlin Wall had relevant consequences also for Italian archaeology. In 1992 the last edition of Dialoghi di Archeologia was published, and by this time it was very distant from the spirit that had animated the creation of the journal in 1967. Carandini distanced himself from Marxist ideology and started to be fascinated by Roman archaic mythology and foundation archetypes.

From this moment onwards, his interest for the so-called regal period of the city considerably increased. The foundation of Rome, and its primeval topography, rather than the social and economic aspects of the Roman world became the focus of his research. This can be observed in works like Palatium e Sacra via I (1995), and La nascita di Roma. Dei, lari, eroi e nomini all'alba di una civiltà (1997). The launch of the latter book was an opportunity for Carandini and Peroni to engage in a debate centered on the contrast between historical and archaeological methods in the study of the past (Carandini 2000: 76). While Peroni saw in Carandini's work a trace of continuity with the statements expressed in Archeologia e cultura materiale, Carmine Ampolo, a professor of Greek History at the University of Pisa whose work was equally centered on the origins of Rome, strongly disagreed with Peroni, labeling Carandini's work as "scientific opportunism" (Carandini 2000; 76). Ampolo was one of the first of a long line of scholars criticizing the new direction of Carandini's work (see among others Bietti Sestieri 2000; Testa 2012; Ampolo 2013). Carmine Ampolo is a historian and archae- 
ologist, who studied at the University of Rome and in the 1970s became a member of the Dialoghi group. One of the most severe criticisms that Ampolo levelled at Carandini regarded the theoretical framework of his later works, where Carandini distanced himself from his original material approach, to turn his interests towards the study of the irrational sphere. Ampolo even accused Carandini of misusing historical sources by mixing heterogeneous approaches (anthropology, history, history of religion, archaeology) with the final goal of validating his interpretation of the discoveries on the Palatine (Ampolo 2013). Ampolo's criticism finds validation in the work of Carandini himself. Throughout his later work indeed Carandini pointed out how his interest shifted through the irrational sphere following his encounter in 1980 with Matte Blanco (Carandini 1981: 258-269; 2000: 80; 2002; 2004: 107). The Chilean psychoanalyst theorized an impact of the unconscious on personality larger than Freud had done with his original tripartition between Id-Ego-SuperEgo. Carandini made abundant use of Matte Blanco's theories to describe the collective subconscious of ancient peoples, which was, in his interpretation, directly linked with their construction of myths.

Following the dissolution of the Istituto Gramsci cluster, Carandini tried to fill this void by applying himself anthropology, history, topography and other disciplines to the study of the past. One of the most frequent criticisms addressed to Carandini, indeed, was that in the later stage of his career he avoided involving other scholars from other disciplines in his research projects. Instead, he isolated himself with the result that the quality of his work was far from reaching the peaks of earlier years (Testa 2012; Ampolo 2013; Giuliani 2012).

Carandini's recent scientific production focuses on the nature of power as well, as in La casa di Augusto. Dai Lupercalia al Natale (2008), Le case del potere nell'antica Roma (2010), and Il fuoco sacro. Vesta, Enea, Romolo (2016). In the last decade, his scientific production was even centered on the history of Christianity. After Romulus, another founding father of Rome caught his attention. Saint Peter became thus the subject of the book Su questa pietra. Gesì, Pietro e la nascita della Chiesa (2013), which was dedicated to the new pope Francis. One of the most interesting aspects is his fascination with archetypical figures of father founders: Romulus, Augustus and S. Peter.

As a provocation, it may be argued that Carandini's latest research interests prallel in a way the nationalist turn that occurred in the eastern block after the fall of Communism. Indeed, in the post Cold War period, national archaeologies (Trigger 1984; Kohl 1998) flourished in the states established following the collapse of federative socialist regimes, and personalities such as, for example, Alexander the Great in the Republic of Macedonia or the emperor Diocletian, in Croatia, became 'father funders' and symbols of these new nation states. (AP)

\section{And Now? Approaches to Archeology in the post-communist Era}

At Sapienza University of Rome, Renato Peroni and Andrea Carandini epitomized the revolutionary forces that renewed archaeology in the 1960s and the 1970s. Carandini has been a pioneer and an experimenter, driven by a limitless curiosity. Open to innovation and change, he merged his hunger for knowledge with a unique education built during his British years and developed within an international intellectual network. He encouraged a group of scholars to experiment with new approaches and to explore 
new research areas. Carandini was a charismatic leader, just like Renato Peroni. The latter, merging the German approach with the Italian Marxist tradition revolutionized Italian Pre- and Protohistory and created a solid school that outlived him. By introducing foreign scientific influences and by recasting them with local research traditions and Marxist ideology, they introduced new theoretical frameworks and interpretative models. However, unlike Peroni, in his later works Carandini abandoned the Marxist interpretative framework in favor of a mythical-historical analysis of the past.

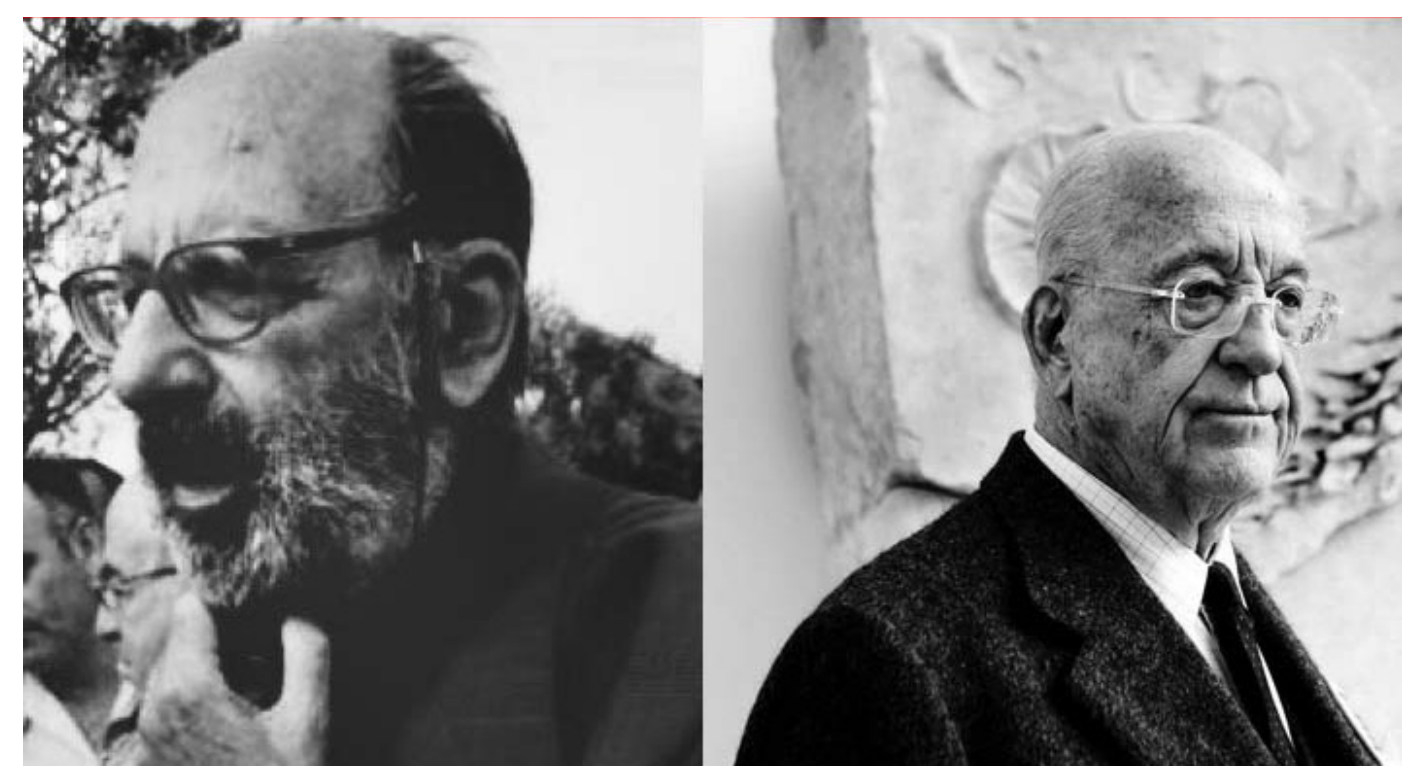

Figure 3. Renato Peroni (left, photograph by R. De Vita) and Andrea Carandini (right, photograph from the Website www.alchetron.com).

Following the fall of Communism, the preeminent role that Marxist ideologies had in the Italian intellectual debate in the 1950s and the 1960s was not replaced by other revolutionary ideas or theoretical approaches. The lively discussions that animated the groups of archaeologists gathered around these two outstanding scholars gradually waned. The lack of a general cultural and political framework seems to have been one of the causes that contributed to the weakening of the original revolutionary wave and led to the stagnation of theoretical approaches that characterize the last decades.

An analysis of the papers published in Dialoghi di Archeologia, can help to understand these phenomena. In Dialoghi, the names of the main authors contributing to the section comprising research papers rarely changed. What was originally conceived as an alternative journal to oppose mainstream and conservative ways of doing archaeology, became conservative itself. Iacono (2014: fig. 4), indeed, has demonstrated that in Dialoghi there was a shift in the number of papers focusing on cultural and political debates, which were replaced by scientific papers. Furthermore, Carandini himself saw another shortcoming in the Dialoghi experience (Carandini 2000: 65): the failed attempt to merge history, philology, archaeology, and epigraphy did not lead to a real evolution in the original subjects. A group of young scholars willing to innovate the discipline slowly became a group of academics not concerned anymore with theoretical issues. 
The challenge of the post-Peroni and post-Carandini era is now open, as archaeology, in primis the 'Roman school' needs to disenfranchise itself from these two major figures and their legacies. Looking at the archaeological discipline in a wider perspective, extending thus this self-reflection to Italy as a whole, at present, the theoretical debate seems to gravitate mainly around two topics: the use of technology and hard sciences in archaeological research, and the exploitation of results and intellectual property. Even if both topics are of overwhelming importance, they cover only partly the need of elaborating new interpretative frameworks and approaches to the discipline. Marxist ideologies represented a driving force in Italian archaeology. They stimulated the elaboration of novel theoretical approaches to the discipline, also thanks to a constant dialogue with foreign scientific realities. Now that their innovative wave seems to be definitively exhausted, it is time for Italian archeology to start a new self-reflexive process and venture on new paths. (EC/MG/AP)

\section{References}

ArchCl. 1962: Archeologia Classica XIV: 115-18, 261-284.

ArchCl. 1963: Archeologia Classica XV: 113-5, 271-273.

ArchCl. 1964: Archeologia Classica XVI: 319-327.

Dialoghi 1967: Dialoghi di Archeologia I: 131-132.

Barbanera, M., 1998. L'archeologia degli italiani. Rome: Editori Riuniti.

Bartoli, E., 2007. Milord. Avventure dell'anglomania italiana. Vicenza: Neri Pozza.

Bianchi Bandinelli, R., 1961. Archeologia e cultura. Rome: Editori Riuniti.

Biettr Sestieri, A. M., 2000. L'archeologia processuale in Italia, o l'impossibilità di essere normali, in: Archeologia teorica. X Ciclo di lezioni sulla ricerca applicata in Archeologia. (Certosa di Pontignano, Siena, 9-14 agosto 1999). Florence: All'Insegna del Giglio, 213-242. Carandini, A., 2004. Logica del mito, in: P. Bria \& F. Oneroso (eds.), La bi-logica fra mito e letteratura: saggi sul pensiero di Ignacio Matte Blanco. Milan: Franco Angeli, 107-113. Carandini, A., 1975. Archeologia e cultura materiale. Dai "lavori senza gloria" nell'antichità a una politica dei beni culturali. Bari: Di Donato.

Carandini, A., 1979. L'anatomia della scimmia. La formazione economica della società prima del capitale. Torino: Giulio Einaudi.

Carandini, A., 1981. Storie dalla terra, Torino: Einaudi.

Carandini, A. (ed.), 1986. Settefinestre, I-III. Modena: Panini.

Carandini, A., 1988. Schiavi in Italia. Gli strumenti pensanti dei Romani fra tarda Repubblica e medio Impero. Rome: Nuova Italia Scientifica.

CARANDInI, A., 1981. Società romana e produzione schiavistica: merci, mercati e scambi nel Mediterraneo. Bari: Laterza.

Carandini, A., 1989. La villa romana e la piantagione schiavistica, in: E. GabBa \& A. Schiavone (eds.), Storia di Roma, IV. Torino: Giulio Einaudi, 101-192.

Carandini, A. (ed.), 1986. Storia di Roma, III, 1. Torino: Giulio Einaudi.

Carandini, A., 2008. La casa di Augusto. Dai Lupercalia al Natale. Bari: Laterza.

Carandini, A., 2000. Giornale di scavo. Torino: Einaudi.

Carandini, A., 2002. Archeologia del mito. Torino: Einaudi. 
Carandini, A., 2010. Le case del potere nell'antica Roma. Bari: Laterza.

Carandini, A., 2013. Su questa pietra. Gesù, Pietro e la nascita della Chiesa. Bari: Laterza.

Cardarelli, A. \& A. Vanzetti, 2014. L'approccio di Renato Peroni allo studio delle società protostoriche dalla fine degli anni '60 del XX secolo, in: A. Guidi (ed.), 150 anni di preistoria e protostoria in Italia, Atti della XLVI Riunione Scientifica IIPP. Roma, $515-521$.

DanCKers, J., 2014. Protostoria italiana e marxismo nell'Italia del secondo dopoguerra, in: A. GuIDI (ed.), 150 anni di preistoria e protostoria in Italia, Atti della XLVI Riunione Scientifica IIPP, Roma, 495-499.

De Francesco, A., 2013. The Antiquity of the Italian Nation. The Cultural Origins of a Political Myth in Modern Italy 1796-1943, Oxford: Oxford University Press.

Giuliani, C. F., 2012. Archeologia oggi. La fantasia al potere. Quaderni di archeologia e cultura classica. Tibur: Tiburis Artistica.

Guidi, A., 2002. An Italian Perspective, in: P. F. Biehl, A. Gramsch \& A. Marciniak (eds.), Archäologien Europas/Archaeologies of Europe. Geschichte Methoden und Theorien/History, Methods and Theory, Tübinger Archäologische Taschenbücher. Munster: Waxmann, 353-360.

Guidi, A., 2015. Quantitative methods in Italian archaeology: a review. Archeologia e Calcolatori 26, 45-58.

Gundle, S., 2000. Between Hollywood and Moscow: The Italian Communists and the Challenge of Mass Culture, 1943-1991. Durham: Duke University Press.

Harari, M., 2012. Etruscologia e fascismo. Athenaeum 100: 405-418.

IACono, F., 2014. A Pioneering Experiment: Dialoghi di Archeologia between Marxism and Political Activism. Bulletin of the History of Archaeology 24.5: 1-10.

Konl, P., 1998. Nationalism and Archaeology: On the Constructions of Nations and the Reconstructions of the Remote Past. Annual Review of Anthropology 27: 223-246.

Nizzo, V., 2015. Archeologia e antropologia della morte. Storia di un'idea. Bari: Edipuglia.

Pallottino, M., 1962. Per una coscienza ed una azione unitaria degli archeologi. Archeologia Classica 16: 115-118.

Peroni, R., 1959. Per una definizione dell'aspetto culturale subappenninico come fase cronologica a sé stante. Rome: Accademia Nazionale dei Lincei.

Peroni, R., 1975. Considerazioni preliminari per l'insegnamento della preistoria. Emilia pre-romana 7: 399-405.

Peroni, R., 1976-77. Dialoghi di Archeologia: 648.

Peroni, R., 1980. Il Bronzo Finale in Italia. Bari: Laterza.

Peroni, R. (ed.), 1981. Necropoli e usi funerari nell'età del ferro. Bari: De Donato.

Peroni, R., 1983. Popoli e facies culturali celtiche a nord e a sud delle Alpi dal $V$ al I secolo a. $C$. Atti del Colloquio Internazionale Milano 14 - 16 novembre 1980. Milan: Comune di Milano.

Peroni, R., 1988. Dalla Società degli Archeologi Italiani all'Albo: motivi per un'unità politica, in: Ancost, Verso una professione, Atti del seminario per l'elaborazione di una proposta di ordine professionale per gli archeologi, Roma 23-24 Febbraio 1988. Mantua: SAP, 76-82.

Peroni, R. \& G.L. Carancini, 1999. L'età del bronzo in Italia: per una cronologia della produzione metallurgica. Perugia: Ali\&no. 
Puglisi, S. M., P. Romanelli, A. Davico \& G. De Angelis D’Ossat, 1951. Gli abitatori primitivi del Palatino attraverso le testimonianze archeologiche e le nuove indagini stratigrafiche sul Germalo. Monumenti Antichi 41: 1-146.

Puglisi, S. M., 1953. Scoperta di tombe arcaiche nel Foro Romano. Rivista di Scienze Preistoriche 8: 1-2.

Puglisi, S. M., 1955. Industria microlitica nei livelli a ceramica impressa di Coppa Nevigata. Rivista di Scienze Preistoriche, 10: 19-36.

Puglisi, S. M., 1959. La civiltà appenninica. Origine e sviluppo delle comunità pastorali in Italia. Firenze: Sansoni.

Testa, A., 2012. Verità del mito e verità della storia. Una critica storico-religiosa a recenti ipotesi sui primordia di Roma. Mediterranea 10: 195-234.

Trigger, B. G., 1984. Alternative archaeologies: nationalist, colonialist, imperialist. Man 19: 355-370.

VitToria, A., 2014. Togliatti e gli intellettuali. La politica culturale dei comunisti italiani (19441964). Roma: Carocci. 
